Dept. of Animal and Poultry Production,

Faculty of Agriculture Assiut University, Assiut, Egypt

\title{
THE EFFECT OF DIFFERENT LEVELS OF DATE SEEDS MEAL ON NEW ZEALAND RABBITS PERFORMANCE
}

(With 4 Tables)

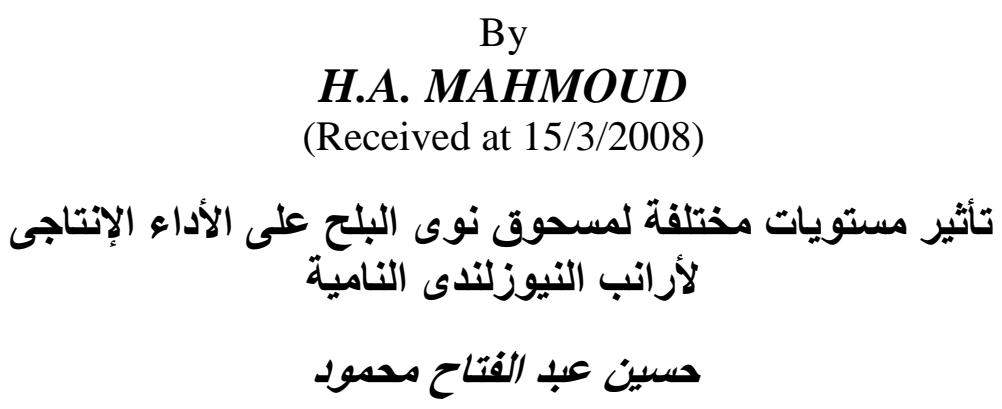

أجريت تجربتين بمزر عة الدواجن بكلية الزراعة جامعة أسيوط أستخدم فى التجربة الأولى إلى

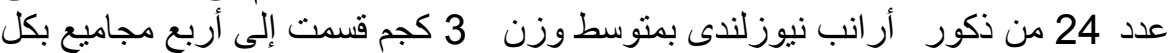

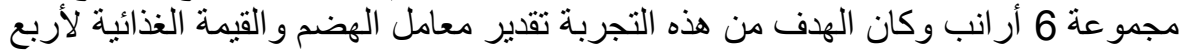

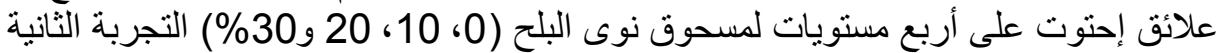

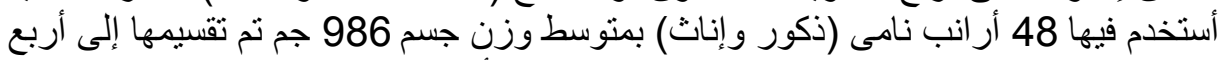

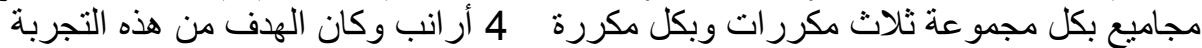

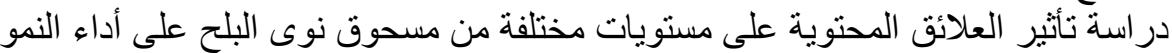

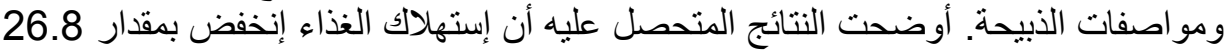

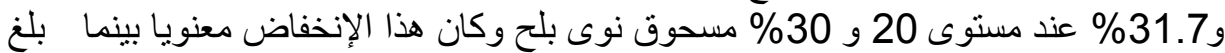

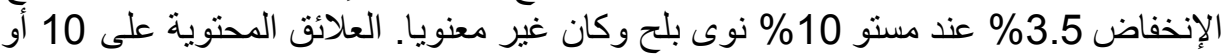

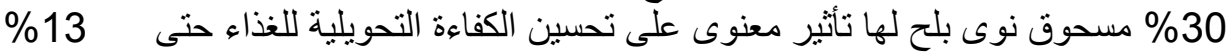

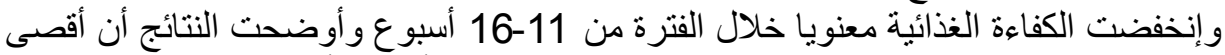

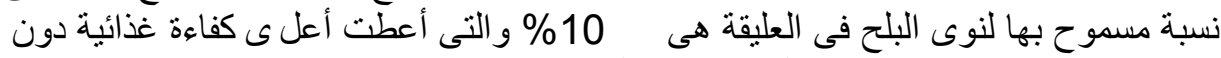

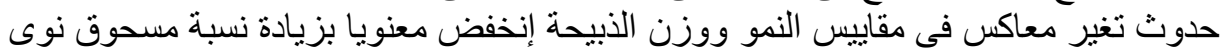

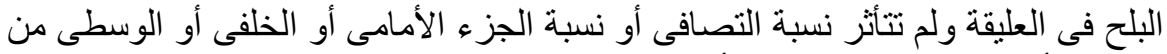

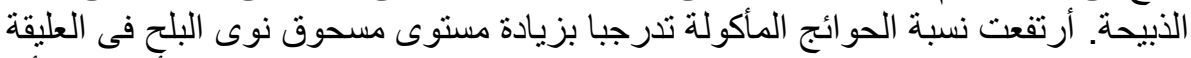

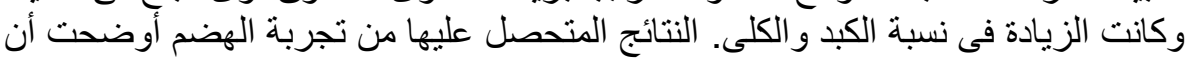

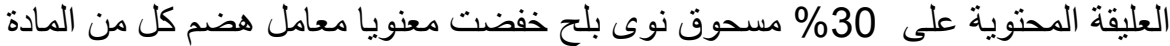

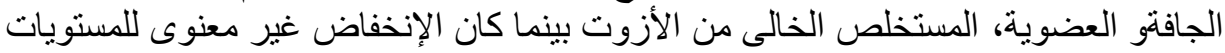

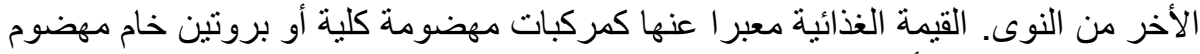
إنخفضت معنويا عند أى مستوى لمسحوق نوى البلائح فئ العليقة. 
Two experiments were conducted at Poultry Farm, Faculty of Agriculture, Assiut University. In the first experiment forty eight New Zealand White rabbits of both sex weaned at six weeks of age, weighing $986 \mathrm{~g}$ on average were randomly divided into 4 experimental treatments (12 rabbit per treatment). Four diets were formulated to be isocaloric and isonitrogenous having 0,10, 20 and 30\% DSM. The experiment aimed to study the utilization of DSM in feeding growing rabbits. Digestibility trial was carried out to evaluate the digestion coefficient and nutritive values of the experimental diets In the second experiment twenty four male New Zealand White adult rabbits (averaged of $3 \mathrm{Kg}$ ) were divided randomly into four groups, six per each. All rabbits were housed individually in galvanized wire cages. Results obtained indicated that the feed intake was significantly decreased as dietary DSM increased. The reduction in feed intake was 26.8 and $31.7 \%$ for the diets contained 20 and $30 \%$ DSM, respectively. The levels of 10 and $30 \%$ DSM significantly $(\mathrm{P}<0.05)$ improved feed conversion up to $13 \%$ during the period of 6-16 weeks of age. However, the feed efficiency was significantly decreased during the $3^{\text {rd }}$ and $4^{\text {th }}$ month of age. The carcass weight significantly $(\mathrm{P}<0.05)$ decreased by increasing dietary DSM levels, while the dressing percent was not affected by DSM levels. No significant effect of DSM levels on forelimbs, hind limbs and loin percentages. However, the kidney and liver percentages were significantly affected by inclusion of DSM in the diets. The results of nutrient digestibility cleared that using diet containing 30\% DSM decreased significantly $(\mathrm{P}<0.05)$ the digestion coefficients of $\mathrm{CP}$. The digestibility of DM, OM, NFE and EE were decreased insignificantly due to DSM inclusion in rabbit's diet by any level. However, digestion coefficients of CF significantly decreased by increasing DSM level. The nutritive values of the experimental diets expressed as TDN, DCP or DE were significantly decreased when DSM represented 10, 20 and 30\% from the diet. The diet contained 30\% DSM had the lowest nutritive value of DCP, DE and TDN. The values of DE were decreased by 13, 18 and $21 \%$ at the level of 10,20 and 30\% DSM, respectively

Key words: Date seed meal, Rabbits, growth performance, digestion coefficient, nutritive value 
The shortage of raw materials such as corn, soybean for the rabbit feed industry has resulted in a continuous increase in the cost of production, causing a phenomenal rise in the unit cost of products. Thus, these products have become too expensive for the majority population in Egypt. Date seed meal (DSM) which is a by-product of packing plants or date juice extraction is an alternative feedstuff that hold some promise if the cultivation of the crop from which it is derived is substantially increased (Tewe, 2002). Palm kernel meal (PKM) is abundant in many tropical regions and is a cheap feedstuff. Babatunde et al., (1975) had earlier reported PKM to be unacceptable to pigs but acceptable by other non-ruminant animal. These views were based on high fiber level of PKM and its gritty nature, which were reported to reduce digestibility, palatability and possibly the availability of nutrients, especially amino acids.

Many investigators reported DSM as an acceptable feedstuff for ruminants and non-ruminants for its high NFE and moderate levels of CP, CF and EE (Kamel et al., 1981; Abou El-Nasr 1985, Khamis et al., 1989, and Abdou, 1996; Agunbiande et al., 1999; and Sundu and Dingle, 2004). However, the information regarding the effect of feeding diets including DSM to rabbits on growth and reproductive performance are limited (EL-Kerdawy et al., 1998). Therefore, the present study was conducted to investigate the digestibility coefficients of nutrients, growth and reproductive performance of New-Zealand White rabbits as affected by partial substitution of corn with different levels of DSM.

\section{MATERIALS and METHODS}

The present study was carried out at the Poultry Farm, Animal and Poultry Production Department, Faculty of Agriculture, Assiut University. Date seed, was purchased from Date manufacturing at New Valley governorate, sun dried for one week, then grinding twice in hummer meal. Two experiments were conducted to investigate the feasibility of using DSM in rabbit's diet at different levels. The first experiment was designed to determine the nutritive value of DSM for mature rabbits, while the second experiment was conducted to evaluate the effect of DSM on growth performance of growing rabbit.

1-Digestibility trial: Twenty four male New Zealand White adult rabbits (averaged $3 \mathrm{Kg}$ ) were divided randomly into four groups, six per each. All rabbits were housed individually in galvanized wire cages. The digestibility trial lasted fourteen days with 8 transitional days followed 
by 6 days for principle period. The first group fed basal diet (0\% DSM, as control) while, the other three groups were fed the basal diet after substituting part of the diet with DSM at 10, 20 and 30\%, respectively. (Table 1). All experimental diets were isocaloric and isonitrogenous and were formulate using Feed Formulation System (1995). The ingredients of the experimental diets were sampled, grinded, mixed thoroughly and analyzed for determination of its different nutrients according to the methods of the AOAC (1990). Along the experiment, each rabbit was offered a weighed amount of the tested diets. Fresh water was automatically available all the time by stainless steel nipple for each cage. During the principle period. The daily fecal matter was collected from each rabbit then weighed, dried, sampled, grinded, mixed and stored to be analyzed for different nutrients.

Digestible energy (DE) values of one kilogram of each experimental diet were calculated according to the equation described by Schieman et al., (1972), cited by Parigi-Bini (1981) as follows:

$\mathrm{DE}(\mathrm{Kcal} / \mathrm{kg})=5.29(\mathrm{DCP}, \mathrm{g} / \mathrm{Kg})+9.51(\mathrm{DEE}, \mathrm{g} / \mathrm{Kg})+4.2(\mathrm{DCF}+$ DNFE, g/ Kg) +0.3

Where DCP, DEE, DCF and DNFE = digestible CP, EE, CF and NFE, respectively

The total digestible nutrients (TDN) value of the diet was calculated by multiplying the digestible ether extract (EE) by the factor 2.25 and multiplying each of digestible crude protein, crude fiber and nitrogen free extract (NFE) by the factor 1.0.

2-Growth trial: Forty eight New Zealand White rabbits of mixed sex, aged 6 weeks, with $986 \mathrm{~g}$ average. The rabbits were equally distributed into four experimental groups, each group consisted of 3 replicates and fed the same four diets as in experiment one. All rabbits were kept under the optimal managerial, hygienic and environmental condition as experiment one.

\section{Variables studied}

1- Digestion coefficient: From the analysis of feed and fecal matter, the digestibility of any nutrient was calculated according to the following equation (Maynard, 1979):

Amount of nutrient intake - amount of nutrient in fecal matter X 100

Amount of nutrient intake

2- Body weight and body weight gain: Rabbits of growth trial were weighed at 6 weeks of age (initial weight) and then every two weeks 
during the experimental period. Final body weight gain was calculated by subtracting initial weight from the weight at the end of the trial.

3- Feed intake and feed efficiency: Feed consumption was estimated on individual basis during the experimental period. Adjusted feed efficiency ( $g$ gain/ $g$ feed) was calculated as:

Live weight gain + gain of dead rabbits at date of death

Feed consumed by live rabbit + feed consumed by dead rabbit until the date of death

4- Carcass traits: At the end of the trial period (16 weeks of age), 12 rabbits (one from each replicate) were weighed then slaughtered after fasting for 12 hours (Lukefahr et al., 1992). After complete bleeding (within 30 minutes), pelt, viscera and tail were removed. The eviscerated carcass was weighed and dressing percentage was calculated. The eviscerated carcass was cut into forelimb, hind limb and loin. These parts were weighed and proportionate to pre-slaughter live body weight and eviscerated carcass, respectively.

5- Statistical analysis: Analysis of variance (ANOVA) was performed on the colleted data with equal subclasses number using the general liner model (GLM) of Statistical Analysis System (SAS, 1995). When a significant main effect was detected, differences between treatment means were tested for significance by Duncan's Multiple Rang Test, (1955) as explained by Steel and Torrie (1960).

. The analysis was carried out according to the following model:

$Y_{i j}=\mu+T i+E_{i j}$

Where $Y_{\mathrm{ij}}$ is the observation of the DSM levels, $\mu$ is the overall mean, $T_{i}$ is the effect of DSM level, $E_{i j}$ is the random error 
Table 1: Composition and chemical analysis of the basal diet.

\begin{tabular}{|c|c|c|c|c|}
\hline Items & $\begin{array}{l}\text { 0\% DSM } \\
\text { (control) }\end{array}$ & $\begin{array}{l}10 \% \\
\text { DSM }\end{array}$ & $\begin{array}{l}20 \% \\
\text { DSM }\end{array}$ & $\begin{array}{l}30 \% \\
\text { DSM }\end{array}$ \\
\hline \multicolumn{5}{|l|}{ Ingredients: } \\
\hline Yellow corn grains & 36.40 & 28.00 & 19.00 & 11.00 \\
\hline Wheat bran & 10.50 & 9.00 & 8.55 & 8.20 \\
\hline Clover hay & 30.30 & 25.80 & 23.80 & 20.00 \\
\hline Soybean meal & 20.20 & 21.70 & 22.70 & 23.65 \\
\hline Date seed meal & ---- & 10.00 & 20.00 & 30.00 \\
\hline Corn Starch & ---- & 2.50 & 2.00 & 2.00 \\
\hline Mixed oil & & & 1.25 & 2.15 \\
\hline Limestone & 1.00 & 1.00 & 1.00 & 1.00 \\
\hline Dicalcium Phosphate & 1.00 & 1.00 & 1.00 & 1.00 \\
\hline Premix $^{1}$ & 0.30 & 0.30 & 0.30 & 0.30 \\
\hline Salt & 0.30 & 0.30 & 0.30 & 0.30 \\
\hline $\begin{array}{l}\text { Total } \\
\text { Chemical Analysis: }\end{array}$ & 100.00 & 100.00 & 100.00 & 100.00 \\
\hline $\mathrm{ME} \mathrm{Kcal/} \mathrm{Kg}$ & 2250 & 2245 & 2248 & 2246 \\
\hline Dry matter & 93.06 & 90.20 & 88.58 & 82.36 \\
\hline Organic matter & 89.43 & 82.70 & 77.40 & 74.63 \\
\hline Crude protein & 18.25 & 18.00 & 18.03 & 18.00 \\
\hline Ether extract & 2.80 & 2.58 & 3.28 & 4.16 \\
\hline Crude fiber & 11.55 & 11.41 & 11.32 & 11.27 \\
\hline Nitrogen free extract & 56.83 & 50.71 & 44.77 & 41.20 \\
\hline
\end{tabular}

${ }^{1}$ One kilogram of premix contained: Vit. A $4000000 \mathrm{IU}$, Vit. $\mathrm{D}_{3} 50000 \mathrm{IU}$, Vit. E $16.7 \mathrm{gm}$, Vit. $\mathrm{K}_{3} 0.67 \mathrm{gm}$, Vit. $\mathrm{B}_{1} 0.67 \mathrm{gm}$, Vit. $\mathrm{B}_{2} 2.0$ gm, Vit. $\mathrm{B}_{6} 0.67 \mathrm{gm}$, Vit. $\mathrm{B}_{12} 3.33 \mathrm{mg}$, Choline chloride $400 \mathrm{gm}$, Biotin $0.07 \mathrm{gm}$, Niacin $16.7 \mathrm{gm}$, Pantothenic acid $6.7 \mathrm{gm}$, Folic acid $1.7 \mathrm{gm}$, Magnesium $133.3 \mathrm{gm}$, Copper $1.7 \mathrm{gm}$, Iodine $0.25 \mathrm{gm}$, Selenium $33.3 \mathrm{mg}$, Iron $25 \mathrm{gm}$, Manganese $10 \mathrm{gm}$ and Zinc $23.3 \mathrm{gm}$

*ME of DSM analyzed by the University of Georgia Poultry Research Farm, Athens, GA 306024356

Table 2: Growth performance of growing rabbits fed different levels of DSM. 
Assiut Vet. Med. J. Vol. 54 No. 117 April 2008

\begin{tabular}{|c|c|c|c|c|c|}
\hline Items & $\begin{array}{l}0 \% \text { DSM } \\
\text { (control) }\end{array}$ & $10 \% \mathrm{DSM}$ & $20 \%$ DSM & $30 \%$ DSM & Significance \\
\hline Number of rabbits & 12 & 12 & 12 & 12 & \\
\hline \multicolumn{6}{|l|}{ Live body weight $(g)$ at : } \\
\hline 6 weeks of age (initial) & $990.6 \pm 37.0$ & $980.0 \pm 24.7$ & $1000.5 \pm 28.3$ & $979.8 \pm 45.1$ & N. S. \\
\hline 11 weeks of age & $1913.3 \pm 43.4^{\mathrm{a}}$ & $1894.5 \pm 56.4^{\mathrm{a}}$ & $1737.0 \pm 57.1^{\mathrm{b}}$ & $1684.2 \pm 68.5^{\mathrm{c}}$ & $*$ \\
\hline 16 weeks of age (final) & $2670.8 \pm 28.7^{\mathrm{a}}$ & $2463.3 \pm 50.4^{\mathrm{a}}$ & $2142.7 \pm 60.1^{b}$ & $2045.3 \pm 76.45^{b}$ & $*$ \\
\hline \multicolumn{6}{|c|}{ Average daily body weight gain (gm) during: } \\
\hline $6-11$ weeks of age & $26.36 \pm 1.4^{\mathrm{a}}$ & $26.13 \pm 1.2^{\mathrm{a}}$ & $21.04 \pm 1.5^{b}$ & $20.12 \pm 1.1^{b}$ & $*$ \\
\hline $11-16$ weeks of age & $21.62 \pm 1.7^{\mathrm{a}}$ & $16.24 \pm 1.6^{\mathrm{b}}$ & $11.59 \pm 1.3^{\mathrm{c}}$ & $10.32 \pm 1.3^{\mathrm{c}}$ & $*$ \\
\hline 6-16 weeks of age (70 days) & $24.00 \pm 0.4^{\mathrm{a}}$ & $21.19 \pm 0.6^{\mathrm{a}}$ & $16.32 \pm 0.6^{b}$ & $15.22 \pm 0.4^{b}$ & $*$ \\
\hline \multicolumn{6}{|l|}{ Daily feed intake (g) during: } \\
\hline 6-11 weeks of age & $98.8 \pm 2.8^{\mathrm{a}}$ & $95.3 \pm 2.4^{\mathrm{a}}$ & $72.3 \pm 3.5^{b}$ & $67.5 \pm 2.7^{\mathrm{b}}$ & $*$ \\
\hline $11-16$ weeks of age & $110.5 \pm 3.3^{\mathrm{a}}$ & $87.0 \pm 2.0^{\mathrm{b}}$ & $75.8 \pm 3.0^{\mathrm{bc}}$ & $64.8 \pm 3.9^{c}$ & $*$ \\
\hline $6-16$ weeks of age & $103.5 \pm 1.7^{\mathrm{a}}$ & $79.3 \pm 2.4^{\mathrm{b}}$ & $72.8 \pm 2.9^{b}$ & $61.8 \pm 0.7^{\mathrm{c}}$ & * \\
\hline \multicolumn{6}{|c|}{ Feed conversion rate (gm feed / gm gain) during: } \\
\hline $6-11$ weeks of age & $3.75 \pm 0.02$ & $3.65 \pm 0.17$ & $3.43 \pm 0.15$ & $3.35 \pm 0.10$ & NS \\
\hline $11-16$ weeks of age & $5.11 \pm 0.70^{\mathrm{a}}$ & $5.35 \pm 0.27^{\mathrm{a}}$ & $6.54 \pm 0.06^{\mathrm{b}}$ & $6.28 \pm 0.18^{b}$ & $*$ \\
\hline 6-16weeks of age & $4.31 \pm 0.17^{\mathrm{b}}$ & $3.74 \pm 0.12^{\mathrm{a}}$ & $4.46 \pm 0.03^{\mathrm{b}}$ & $4.06 \pm 0.09^{\mathrm{ab}}$ & $*$ \\
\hline \multicolumn{6}{|l|}{ Survivability (\%) during: } \\
\hline 6-11 weeks of age & 91.67 & 100.00 & 91.67 & 91.67 & NS \\
\hline $11-16$ weeks of age & 100.0 & 91.67 & 100.00 & 90.90 & NS \\
\hline 6-16 weeks of age & 91.67 & 83.33 & 91.67 & 83.33 & NS \\
\hline
\end{tabular}

acb means within a row within the same character, with different superscripts are significantly different $(\mathrm{P}<0.05)$ Statistical significant by analysis of variance, NS $=$ not significant.

Table 3: Nutrients digestibility and feeding values of the experimental diets. 
Assiut Vet. Med. J. Vol. 54 No. 117 April 2008

\begin{tabular}{|c|c|c|c|c|c|}
\hline \multirow{2}{*}{ Items } & $\begin{array}{c}\text { 0\% DSM } \\
\text { (control) }\end{array}$ & $10 \%$ DSM & $20 \%$ DSM & $30 \%$ DSM & Significance \\
\cline { 1 - 5 } $\begin{array}{c}\text { Nutrients } \\
\text { digestibility (\%) }\end{array}$ & $78.25 \pm 1.23$ & $79.79 \pm 1.17$ & $77.40 \pm 1.16$ & $78.08 \pm 2.64$ & N.S. \\
\hline Dry matter & $81.15 \pm 1.52$ & $79.65 \pm 1.11$ & $77.27 \pm 1.24$ & $75.48 \pm 1.56$ & N. S. \\
\hline Organic matter & $82.53 \pm 1.55^{\mathrm{a}}$ & $79.93 \pm 1.54^{\mathrm{a}}$ & $77.83 \pm 1.62^{\mathrm{a} b}$ & $74.20 \pm 1.66^{\mathrm{b}}$ & $*$ \\
\hline Crude protein & $38.34 \pm 1.82^{\mathrm{a}}$ & $15.15 \pm 1.67^{\mathrm{b}}$ & $12.95 \pm 0.73^{\mathrm{b}}$ & $8.3 \pm 1.75^{\mathrm{c}}$ & $*$ \\
\hline Crude fiber & $92.14 \pm 0.34$ & $89.91 \pm 0.52$ & $91.45 \pm 0.94$ & $91.59 \pm 1.43$ & N. S. \\
\hline Ether extract & $78.52 \pm 1.71$ & $76.10 \pm 1.79$ & $77.16 \pm 1.41$ & $76.55 \pm 1.82$ & N. S. \\
\hline NFE & & & & & $*$ \\
\hline Feeding values & $3102 \pm 65^{\mathrm{a}}$ & $2693 \pm 46^{\mathrm{b}}$ & $2540 \pm 58^{\mathrm{c}}$ & $2433 \pm 67^{\mathrm{d}}$ & $*$ \\
\hline DE (Kcal /kg ) & $72.58 \pm 1.10^{\mathrm{a}}$ & $64.95 \pm 0.95^{\mathrm{b}}$ & $65.41 \pm 0.1 .20^{\mathrm{b}}$ & $60.30 \pm 0.97^{\mathrm{c}}$ & $*$ \\
\hline TDN (\%) & $15.06 \pm 0.26^{\mathrm{a}}$ & $14.34 \pm 0.26^{\mathrm{a}}$ & $14.03 \pm 0.27^{\mathrm{bc}}$ & $13.35 \pm 0.27^{\mathrm{c}}$ & $*$ \\
\hline DCP $(\%)$ &
\end{tabular}

abcd means within a row within the same character, with different superscripts are significantly different $(P<0.05)$ Statistical significant by analysis of variance, NS = not significant

Table 4: Carcass traits of growing rabbits fed different levels of DSM

\begin{tabular}{|c|c|c|c|c|c|}
\hline Items & $\begin{array}{r}0 \% \text { DSM } \\
\text { (control) }\end{array}$ & $10 \% \mathrm{DSM}$ & $20 \%$ DSM & $30 \%$ DSM & \multirow[t]{2}{*}{ Significance } \\
\hline No. of Animals & 3 & 3 & 3 & 3 & \\
\hline Pre slaughter weight (gm) & $2650.7 \pm 55^{\mathrm{a}}$ & $2410.2 \pm 63^{b}$ & $2128.6 \pm 51^{\mathrm{bc}}$ & $2028.8 \pm 61^{\mathrm{c}}$ & $*$ \\
\hline Carcass weight (gm) & $1449.4 \pm 74$ & $1328.1 \pm 46$ & $1150.9 \pm 46$ & $1121.5 \pm 53$ & $*$ \\
\hline Dressing $(\%)$ & $54.68 \pm 0.9$ & $55 . .10 \pm 0.8$ & $54 . .07 \pm 1.3$ & $55 . .30 \pm 0.6$ & NS \\
\hline Fore limb $(\%)$ & $32.6 \pm 1.2$ & $32.9 \pm 1.5$ & $33.7 \pm 0.9$ & $34.5 \pm 0.8$ & NS \\
\hline Hind limb $(\%)$ & $37.2 \pm 0.9$ & $36.3 \pm 1.4$ & $37.0 \pm 1.6$ & $36.7 \pm 1.3$ & NS \\
\hline Loin $(\%)$ & 11. \pm 0.9 & $11.0 \pm 0.6$ & $10.9 \pm 0.8$ & $11.1 \pm 1.1$ & NS \\
\hline Edible organs weight $(\%)^{1}$ & $4.51 \pm 0.14$ & $5.70 \pm 0.32$ & $5.75 \pm 0.46$ & $5.99 \pm 0.37$ & $*$ \\
\hline Heart $(\%)$ & $0.37 \pm 0.0$ & $0.35 \pm 0.02$ & $0.36 \pm 0.01$ & $0.34 \pm 0.01$ & N.S. \\
\hline Kidneys (\%) & $0.75 \pm 0.03^{b}$ & $0.76 \pm 0.03^{b}$ & $0.72 \pm 0.06^{\mathrm{a}}$ & $0.76 \pm 0.0 .5^{\mathrm{a}}$ & $*$ \\
\hline Liver $(\%)$ & $3.35 \pm 0.15^{\mathrm{b}}$ & $4.56 \pm 0.34^{\mathrm{a}}$ & $4.67 \pm 0.35^{\mathrm{a}}$ & $4.89 \pm 0.08^{\mathrm{a}}$ & $*$ \\
\hline Lungs (\%) & $0.77 \pm 0.01$ & $0.75 \pm 0.03$ & $0.80 \pm 0.02$ & $0.82 \pm 0.05$ & NS \\
\hline
\end{tabular}

abc means within a row within the same character, with different superscripts are significantly different $(\mathrm{P}<0.05)$ Statistical significant by analysis of variance, $\mathrm{NS}=$ not significant 
The effects of DSM level on body weight, body weight gain, feed consumption, feed efficiency and survivability are shown in Table (2). The results relating to growth performance were used to determine the acceptable optimum level of DSM in growing rabbit diets. The obtained data indicated that the level of dietary DSM significantly affected $(\mathrm{P}<0.05)$ the growth traits and the incidence of enteritis mortality in rabbits for the whole period. The rabbits fed diet contained 30\% DSM had the lowest body weight and body weight gain while, the control group recorded the highest values. The level of 10\% DSM had no significant effect on body weight and body as compared with a control group. Feed intake was significantly decreased as dietary DSM increased. The reduction in feed intake was 26.8 and $31.7 \%$ for the diets contained 20 and $30 \%$ DSM, respectively. The reduction (3.5\%) in feed intake of rabbits fed 10\% DSM was not significant. During the period from 6 to 11 weeks there is no significant difference detected in the feed conversion. Compared with the other treatments, 10 and 30\% DSM significantly $(\mathrm{P}<0.05)$ improved feed conversion by up to $13 \%$ when added to the growing rabbit diets during the period from 6 to 16 weeks of age. However, the feed efficiency was significantly decreased during the $3^{\text {rd }}$ and $4^{\text {th }}$ month of age. The results related to feed consumption and feed conversion revealed that using DSM at 10 or $30 \%$ levels led to an improvement in feed efficiency values due to the decreasing feed intake for those diets. Decreasing the feed consumption of rabbits were received $30 \%$ DSM may be due to using the oil in the diet and it may increase the utilization from DSM. These results were supported with the findings of Attia (1994) who detected significant decrease in feed consumption for growing rabbit receiving diets containing 5, 10, 15 or $20 \%$ ground date pits during the period from 5-12 weeks of age. Similarly, Aboul-Ela et al. (2000) reported that incorporating ground date pits (GDP) at levels of 5, 10,15 and $20 \%$ in the rabbit diet has resulted in a decrease of 360, 456, 723.26 and $745 \mathrm{~g}$ than the final gain of the control diet. However, Jumah et al., (1973) reported that with incorporating DSM at the level of $15 \%$ in the broiler diet which had resulted in a significant decrease in final body weight that amounted to $178.3 \mathrm{~g}$ less to control diet at 8 weeks of period. The feed conversion was increased with increasing the dietary date pits levels from 5 to $20 \%$. Also, they observed insignificant increase in feed consumption for chicks receiving diets containing 5,10 or $15 \%$ date pits compared with birds fed control diet.

There are several possible explanations for low growth rate of rabbits fed high-DSM diets, as mentioned by Lablace and Lebas (1977), 
finely ground feed increased the retention time of digesta in the secum, decreasing the dry matter intake and highly digestible diets are consumed in lower quantities and retained in the digestive for long time. According to survivability, no significant effect was detected among the DSM levels. So the acceptable maximum level of dietary DSM in the present study was $10 \%$, in which greatest values for efficiency of feed utilization were recorded, while 30\% DSM had improved feed conversion without adversely effect on survivability

Concerning the effect of DSM on carcass traits (Table 3), the obtained results cleared that the rabbits fed diet had 30\% DSM produced the best dressing percent, while those fed diet containing 20\% DSM gave the lowest one. The carcass weight significantly $(\mathrm{P}<0.05)$ decreased as increasing dietary DSM levels, while the dressing percent was not affected by DSM levels. No significant effect of DSM levels on fore limb, hind limb and loin percentages. These results mean that the effect of DSM was appeared on live body weight and body weight gain, while it was disappeared on dressing, fore, hind limbs and lion percentages. However, the kidney and liver percentages were significantly affected by inclusion of DSM in the diets. The edible organs were gradually increased by increasing the DSM levels. These results were supported with the findings of Sharof (1968) who reported that date seeds increased organ weights (heart, liver, spleen, kidney and ovary) in rabbit and chickens. Whether differences in DSM would have an important effect on liver and kidney is not known and need more studies.

Collectively, from the previous findings, it is cleared that the DSM level explains the main variations observed in the growth traits, and carcass traits. So, the suitable level of dietary DSM for growing New Zealand rabbits is between 10 to $20 \%$ with $18 \% \mathrm{CP}$ and $2250 \mathrm{Kcal} / \mathrm{Kg}$ ME.

Concerning the results of nutrient digestibility, Table (3) cleared that using diet containing 30\% DSM in growing rabbits diet decreased significantly $(\mathrm{P}<0.05)$ digestion coefficients of crude protein compared with other treatment groups. The digestibility of DM, OM, NFE and EE decreased insignificantly at DSM inclusion in the growing rabbits diets at any level. However, digestion coefficients of CF significantly decreased by increasing DSM levels. The digestion coefficient of CF decreased by $60.5,66.2$ and 78.4\% when DSM was used at levels of 10, 20 and 30\%, respectively. A similar finding was reported by EL-Kerdawy et al, (1998) and Aboul-Ela et al., (1999) who observed similar trends with CF digestion coefficients. The results obtained from this study revealed that 
using DSM at level of $10 \%$ had no significant adverse effect on digestion coefficients of DM, OM, CP, EE, and NFE, this means that using this level is safe for growing rabbits..

The nutritive value of the experimental diets expressed as TDN, DCP or DE significantly decreased when DSM represented 10, 20 and $30 \%$. The diet contained 30\% DSM had the lowest nutritive values of DCP, DE and TDN. The values of DE were decreased by 13, 18 and $21 \%$ at the level of 10, 20 and 30\% DSM, respectively. The observed decrease in the nutritive value of the diet containing 30\% DSM may be attributed to the depression in digestibility of all nutrients which occurred in this treatment. The previous results obtained on nutrients digestibility and nutritive value of the experimental diets are in good agreement with those obtained by EL-Kerdawy et al. (1998) who observed that the adult rabbits can tolerate up to $10 \%$ date seeds in their diets without any adverse effect on digestion coefficients of nutrients or efficient utilization of these diets.

Generally, it could be concluded that from the nutritional efficiency stand point of view, the DSM could be used successively and safe in formulating diet for growing rabbits up to $10 \%$ without adversely affecting their growth performance, carcass traits, digestion coefficient and nutritive values. Where New-Valley Date trees are produced in large numbers for their date processing, the date seeds residue can be used as a local substitute for imported feed ingredients. The low-energy value of DSM needs to be balanced with a high-energy fat source to meet the energy needs of rabbits, however, more information is needed about its amino acids availability and fiber fractions.

\section{REFRENCES}

Abdou, A.M. (1996): Effect of ammoniation on date seeds utilization in dairy ration, Ph. D. Thesis, Faculty of Agriculture, Cairo University, Egypt.

Abou El-Nasr, H.M. (1985): A study on possibility of using desert agricultural by-products in feeding livestock. Ph. D. Thesis, Faculty of Agriculture, Cairo University, Egypt.

Aboul-Ela, S.; El-Hindawy, M.; Sherif, S.Y.; Tawfik, E.S. and Attia, A. I. (1999): Evaluation date pits as waste product of food industries in feeding NZW rabbits. International Conference on rabbit production in hot climates Zaragoza: CIHEAMIAMZ, 1999.

Agunbiande, J.A.; Wiseman, J. and Cole, D. J.A., (1999): Energy and nutrient use of palm kernels, palm kernel and palm kernel oil 
in diets for growing pigs. Anim. Feed Sci and Technology, 80: 165-181.

Association of Analytical Chemists, AOAC, (1990): Official Method of Analysis $15^{\text {th }}$ ed. Association of Anlytical Chemists, Washington, DC.

Attia, A.I. (1994): Studies on rabbit feed and feeding, Thesis, Faculty of Agriculture, Zagazig University, Egypt.

Babatunde, G.M.; Fetuga, B.L.; Odumosu, O. and Oyenuga, V.A. (1975):

Palm kernel meal as a major protein concentrate in the diet of pigs in tropics. J. Sci. Food Agr. 26: 1279-1291.

Ducan, D.B. (1955): Multiple range and multiple-F-test, Biometrics 11: $1-42$.

EL-Kerdawy, D.M.A., Ibrahim, H. and Soad, S.A. (1998): Reproductive performance of New Zealand White rabbits as affected by partial substitution of barley with date seeds.

Feed Formulation System (1995): The Brill Corporation (version 7) 2250 Northwinde, Parkway. Suite 225. Alpharetta, GA 30004, USA.

Jumah, H.F.; Al-Azzawi, I.I. and Al-Hashimi, S.A. (1973): Some nutritional aspects of feeding ground date pits of broiler. Mesopotamia Journal of Agricultyre, 8 (2): 139-146

Kamel, B.S.; Diab, M.F.; Ilian, M.A. and Salman, A.J. (1981): Nutritional value of whole date and date pits in the chick. Poul. Sci. 60: 1005-1011.

Khamis, H.S.; El-Shaer, H.M.; Farid, M.F.A.; Shalaby, A.S. and Salem, O.A. (1989): Utilization of date seeds and olive pulp as supplementary feed for lactating ewes in Sinai, Third Egyptian-British Conference on Animal, Fish and Poultry Production, Alexandria, 7-10 October, 103-0109.

Laplace, J.P. and Lebas, F. (1977): Le tmisit digestifchez les monogasteiques. 1 athogenie des diarrhees chez le lapin, Ann. Zootech, 27, 225-265.

Lukefahr, S.D.; Van Vieck, L.D. and Roberts, J.D. (1992): Estimates of components of variance and covariance of carcass traits in rabbits using animal model. Journal of Applied Rabbit Research, 15: 259-273.

Maynard, L.A. (1979): Animal Nutrition. $7^{\text {th }}$ ed. McGraw-Hill Book Company, Inc., New York, Toronto, London.

Parigi-Bini, R. (1988): Recent development and future goal in research on nutrition of intensively reared rabbits. Proceeding $4^{\text {th }}$ 
Congress of the World Rabbit Association, 3:1-28 Budapest, Hungary.

SAS Institute (1992): SAS User's Guide: Statistcs. Version 6, SAS Institute, Cary, NC.

Schiemann, R.; Nehring,K.; Hoffman, I.; Jentsch, W. and Chudy, A. (1972): Energetische futterbewertung und energienormen, VEB, Deutscher landwirtschaftsvering, Berlin, p 344

Sharof, M. (1968): "The future of Animal Wealth in Arab World". The Arab Writer House for Printing and Publication.

Steel, R.G.D. and Torrie, J.H. (1960): Principles and procedures of statistics Mc Graw-Hill Book Co., Inc., New York, Ny.

Sundu, B. and Dingle, J. (2004): Use of enzymes to improve the nutritional value of palm kernel meal and copra meal. Proc. Quensland Pult. Sci. Symp. Australia, Vol: 11 (14) 1-15.

Tewe, O.O. (2003): Economics of the commercial utilization of Local and alternative feed resources. Proc. Of the 28th Annual Conf. of the Nigerian Society for Animal production. 28: 466- 468. 